\title{
APPLICATION OF INFORMATION RETRIEVAL ROOM IN BUILDING A8 FACULTY OF ENGINEERING SURABAYA STATE UNIVERSITY WEB-BASED AND VIRTUAL REALITY
}

\author{
Fatkul Ikrom Ariszki ${ }^{1}$, Nurhayati Nuhayati ${ }^{2}$ \\ 1,2 Jurusan Teknik Elektro, Fakultas Teknik, Universitas Negeri Surabaya \\ Email: ${ }^{1}$ fatkulariszki@mhs.unesa.ac.id \\ Email: ${ }^{2}$ nurhayati@unesa.ac.id
}

\begin{abstract}
Technology plays an important role in human life today, the ease of accessing the internet makes information technology a tool to help humans in their daily lives, one of which is a tool that can find new locations. The high use of search engines makes search engines the choice that is often used in finding information. This research was conducted to implement the Information Retrieval(IR) system to find rooms in the Engineering Faculty, Surabaya State University. The system will perform keyword indexing (query) to documents that are already stored in the MySQL database. This IR system is loaded on a Web page, equipped with general information about the room, the room's location point (Maps), and a Virtual Reality display that can provide users with a room browsing experience. The results of the study were a room search system website equipped with VR which was rated well by users with an average rating of $78 \%$. From the results of this research, the IR web system is suitable for use as a medium to provide information and instructions for rooms in building A8, Faculty of Engineering, State University of Surabaya. In the management of information media, it is necessary to improve the quality of information and services, to support the needs of users so that information technology media can be used by users who are not familiar with the Surabaya State University environment.
\end{abstract}

Kata Kunci: Information Retrieval, MySQL, Query, Web.

\section{INTRODUCTION}

In this era of globalization, almost all human activities are connected to the internet, both wired and wireless. As a result of the survey conducted by APJII (Asosisai Indonesian Internet Service Provider), the number of Internet users in 2017 to 2018 increased by $10.12 \%$ from the previous year, increasing by 27.91 million to 171.18 million users, in the previous year there were 143.26 million users. [1]. The rapid development of technology and the high role of information technology in human life to facilitate in finding new places or have never been visited, the use of search engines (search engines)to find new locations, become one of the superior functions in daily use. To find a room that has never been visited by someone in the State University of Surabaya, especially the Faculty of Engineering will take time and less effective if one conducts a manual search, moreover Surabaya State University has an area of 22 hectares in the Ketintang Area and 82 hectares in the Tongue Area of Wetan. It is divided into 5 faculties located in 2 different locations. [2] . The breadth of the campus area, the number of rooms, and the spread of the room will make the room difficult to find, especially for visitors who have never visited the room. The high use of search engines makes people use search engines more in finding things. From the results of a survey conducted by APJII in 2017 on Internet User Behavior, Indonesia projects Search Engines to be ranked 3rd in services accessed by Internet users in Indonesia, namely $74.84 \%$ of all Internet users in Indonesia using Search Engines. [3] .

Every individual or human being is always closely related to information. Information can be likened to an object or a real presentation of knowledge. Information in the form of tangible objects, presented in the form of a series of symbols or images that can be captured by the five senses. Concerning Information Systems, information can be defined as a structured dataset of information delivered through voice, image, video, and other understandable matters. Teskey's opinion [4] According to him, information is a structured data set that a person conveys to others. Gordon B. Davis [5] also provides definitions of information. According to him, information from the point of view of the information system is data that has been processed into a form that is meaningful for the recipient and useful in making current or future decisions

Search engines required media that can provide complete information for users so that users get the desired information and good experience when using retrieval information. Based 
on this understanding, the presentation of room search results data must be presented in a complete, accurate and accompanied by other supporting information such as; room profile information, lecturer's name and room responsibility, location in the form of maps, facilities in the room, and guides in the form of directions to the room in the form of virtual reality, text directions.

This research refers to several previous studies, namely research conducted by Ariyanti, [6]. Build online information about the geography of several universities located in the city of Bengkulu. However, this system has a disadvantage that the user must select the desired object (campus) in the list of available options, this is less efficient if the number of objects provided is more than 20 , the user will have difficulty finding the desired object.

In the previous year has been researched by Purnomo [7] Implementing geographical tourist locations in the Special Region of Yogyakarta, in this study users or prospective tourism visitors can find the coordinates of the desired tourist location. This Geographic System does not display details of other information such as supporting images or directions. This will make it difficult for potential visitors who do not know the road to tourist sites.

Sariningrum [8] developed the Information Retrieval System for The Search for Health Facilities in Solo Region where users can search for the desired hospital with the location point of the hospital shown on the map. On the other hand, users do not get detailed information about each room presented. This study has shortcomings in the presentation of visual information that can provide a browsing experience for users.

The three studies above are less effective if users want to find more detailed, detailed, and accessible information. From the background above, the purpose of the research to be achieved is (1) to create a room meeting system in building A8 Faculty of Engineering Surabaya State University as a medium of information to find a campus room equipped with general information about the room, directions from various accesses available, presented in a web page and equipped with virtual reality,(2) Knowing the user's response to the results of making the IR system of the room in Building A8 Faculty of Engineering, State University of Surabaya. From this research has been created a room search system website equipped with virtual reality that is rated good by users with an average rating of $78 \%$.

\section{METHOD}

The approach in this research is quantitative because the research is presented with figures. This is following Arikunto's opinion. In this research, the process of designing and implementing IR uses MySQL as Database management. The data that will be used in this study is obtained by conducting surveys, field observations to find out the name of the room, room number, room location, position of the floor of the room, and the number of rooms in the Faculty of Engineering building. In addition to taking room and building data, 360-degree shooting also uses this method for image input used for virtual reality media.

This section explains how the research was done. The subject matter of this section is (1) research design; (2) population and sample (research objectives); (3) data collection and instrument development techniques; (4) and data analysis techniques. For research that uses tools and materials, it is necessary to write down the specifications of the tool and its materials. Specifications of the tool describe the sophistication of the tool used while the specifications of materials describe the kinds of materials used.

This design system is based on an internet network that uses a commercial server as the main database system, all complementary data (maps and Virtual Reality) is also accessed through an internet network. The user will enter a keyword(query)that corresponds to the name of the room/room code you want to go to, then the system will do a data matching query with the database available, Some data that matches in the form of Room Name, Room Code, Floor on Building, Building Name that will be displayed into the search results list page, then the user can choose the desired room, then the user will get a clue data in the form of an explanation of the direction of the road to get to the selected room, the location of the room, brief information about the room, and Google Maps that has been integrated with the system and available in each room, this will make it easier for users to know where the room is in the building. Users can also see the surrounding conditions of the room and access the surroundings of the room in the form of Virtual Reality or $360^{\circ}$ View.

Media information in the form of Virtual Reality displays is composed of several images that have been recorded previously in the data collection in field study activities, the images taken are the condition of each corner in the building and the access hall to the room. The picture taken is 5 meters away from the other images. The image data that has been collected will be integrated into the room information page as a Virtual Reality that can later be used as a medium of information that can display the condition around the room and the access road to the room The distance between the user and the intended location has an infinite distance. The use of directions can make it easier for the user to get to the room they are going to. The user is presented with directions from several doors that can be used to get to the desired room. The entrance of the building will be the starting point of the trip and the intended room will be the final destination of the trip. These instructions will be displayed in the room information on the search results page Besides, Google Maps can be used as directions to the desired building making it easier for users to reach the intended building. follows:

The overall system design can be seen in Figure 4 as 


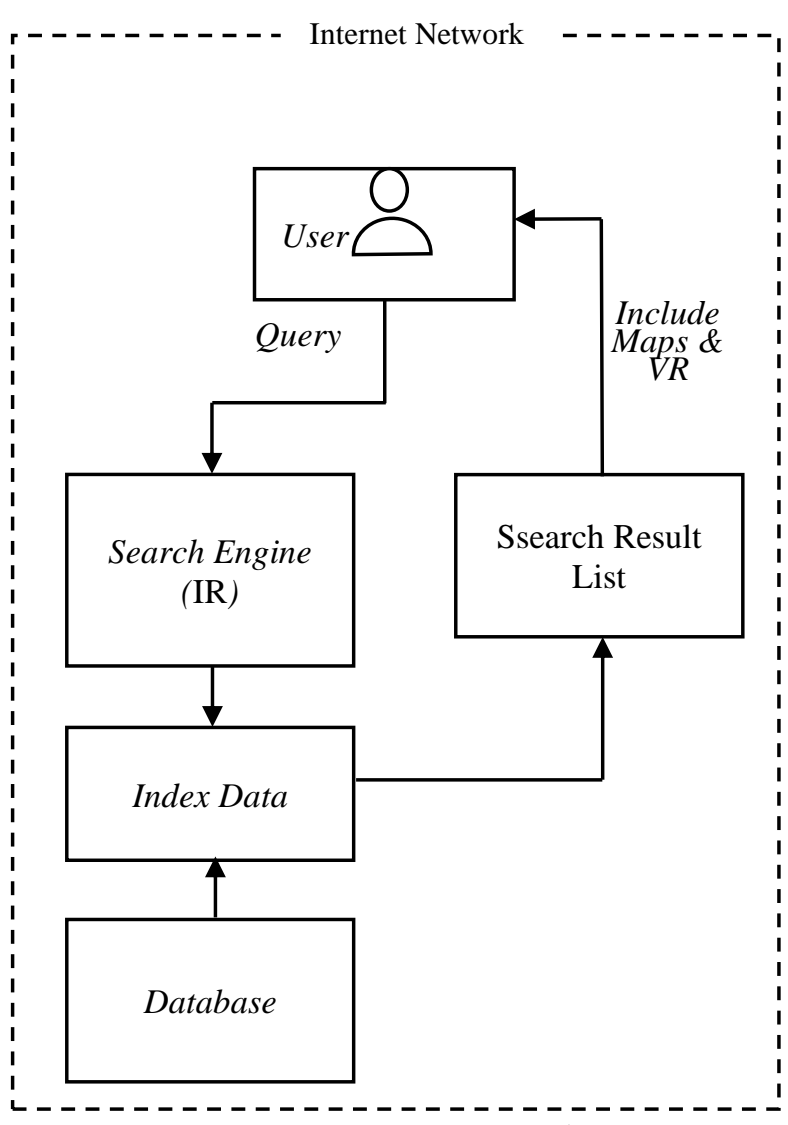

Figure 4. System Design

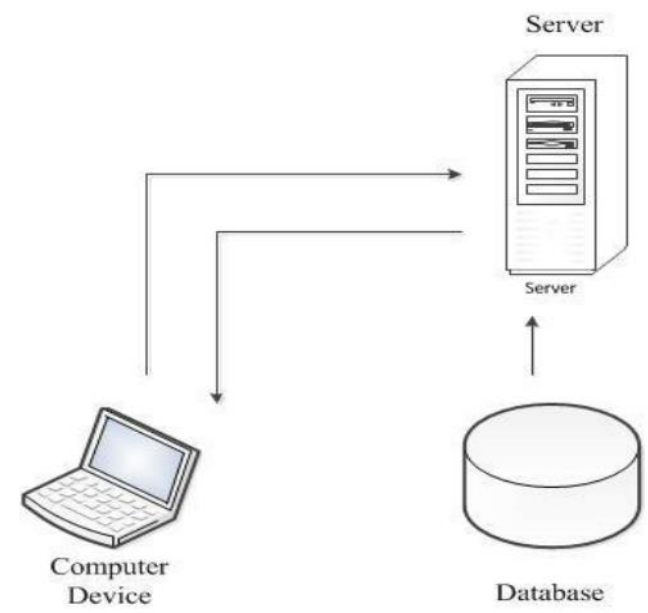

Figure 5. System Working Principles

This IR system can only be accessed through the internet network and can be accessed by anyone connected to the internet network. All complementary data(maps and Virtual Reality)are also accessed through the internet network.

\section{Information Retrieval Method}

In keyword processing(query)to get the data desired by the user, it takes the performance of the system to retrieve online data. This study uses the Boolean Information Retrieval method with OR Logic, this system matched the words entered by the user with the database, and then the data containing the word elements entered by the user will be displayed on the search results page and data that does not contain the word element will not be displayed in the search results.

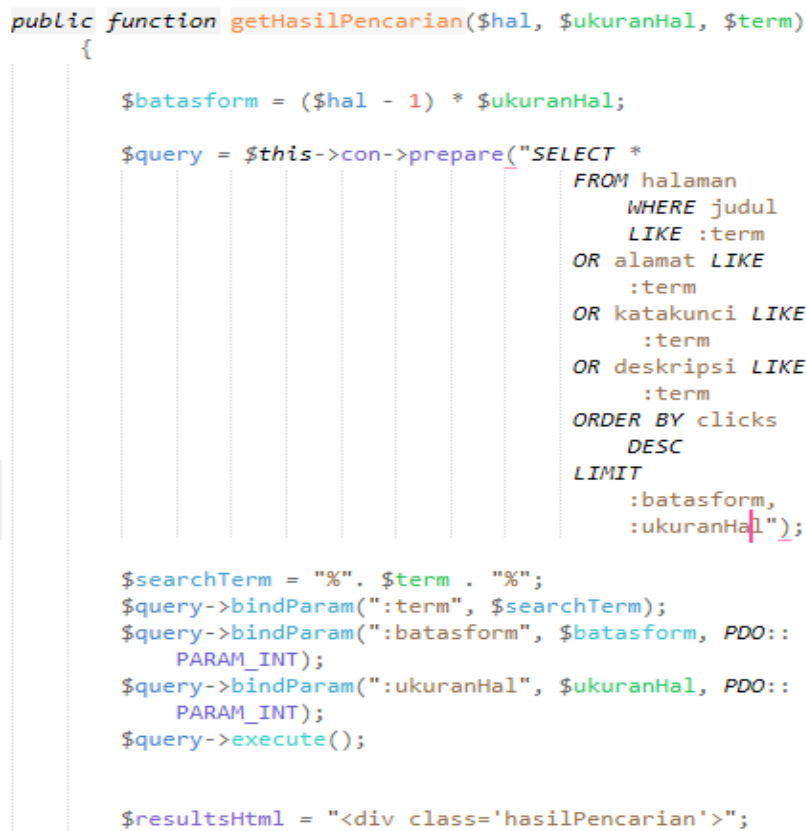

Figure 6. Program IR Code syringe Using Boolean OR Method

Keywords entered by the user will be matched with the data Title, Address(room number and building name), keywords (room keywords in the database), $a$ general description of the room. All room search results will be sorted according to the number of clicks already recorded in the database, ranging from the largest number of clicks to the smallest number of clicks.

\section{How The Program Works}

To answer the problem in order to formulate conclusions in this research, flow diagrams of how the program works are made as described in Figure 5 as follows: 


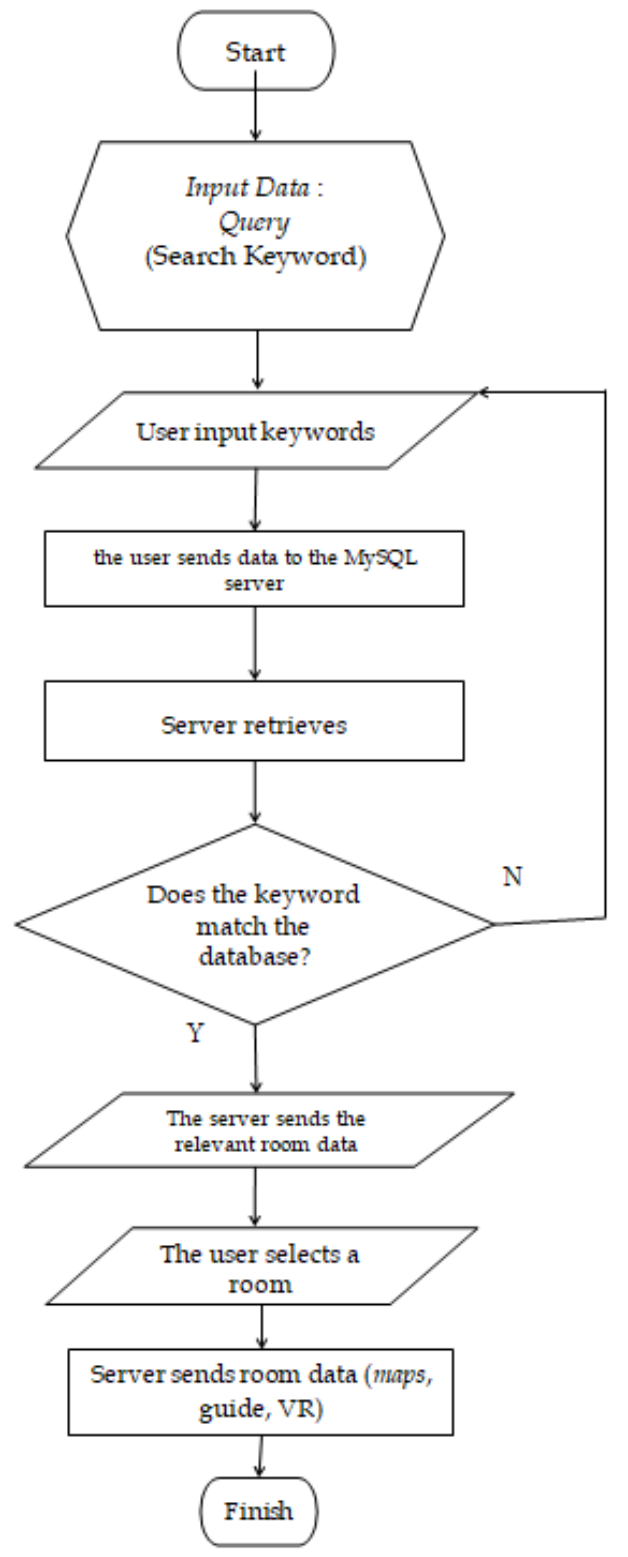

Figure 7. Design Face Work System

\section{RESULT AND DISCUSSION}

\section{Design Phase}

The data contained in the MySQL database contain several stored data namely the page address of each room, general information of each room, room instructions, and room location data, in the room data table as shown in figure 7.

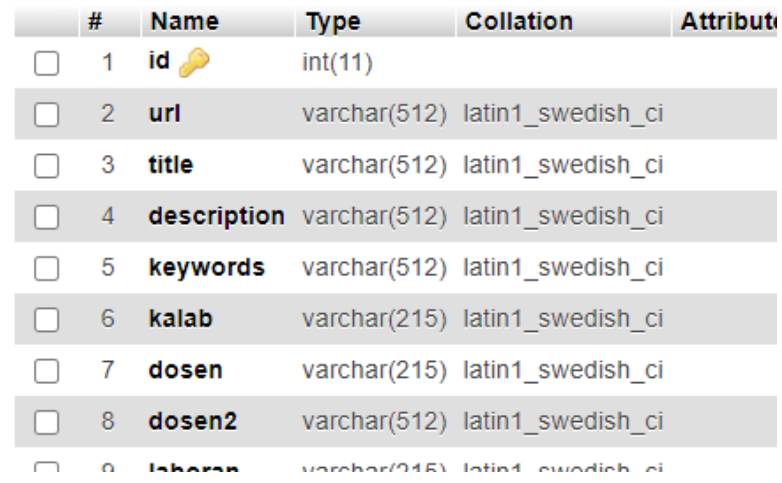

Figure 8. Database page

In the room table, there are 5 columns containing information about the room as shown in the picture

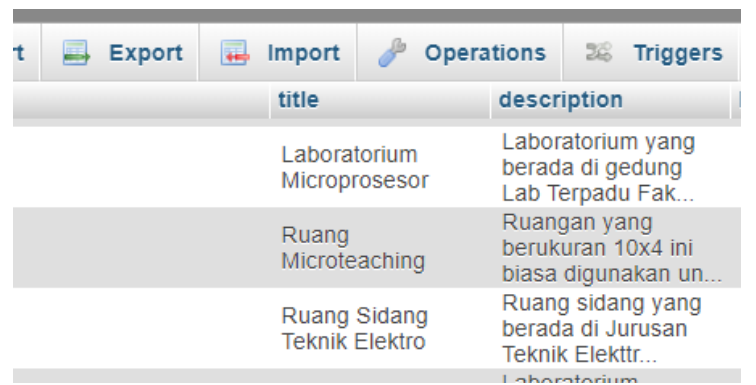

Figure 9. Database page

To meet the needs of online storage researchers use dedicated hosting to store virtual reality images because each image has a size of more than6 MB. In this study using http://postimage.cc

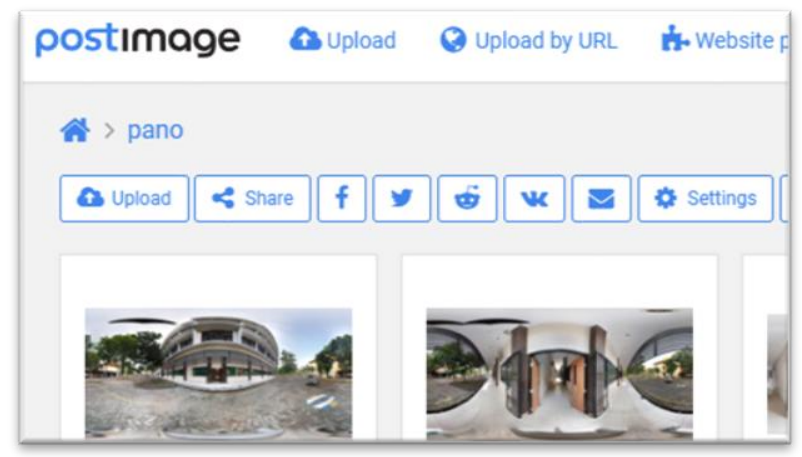

Figure 10. Image hosting

The programming language used to create these IR web pages is the HTML programming language that comes with $a$ Cascading Style Sheet (CSS) to organize the appearance written in HTML. The use of javascript in this study serves as an additional interactive feature for users when accessing IR systems. The processing of search data in this study is contained in the PHP programming 
language (Hypertext Preprocessor). The language piece is in figure 9.

programming

\section{/public_html/ceck1.html}

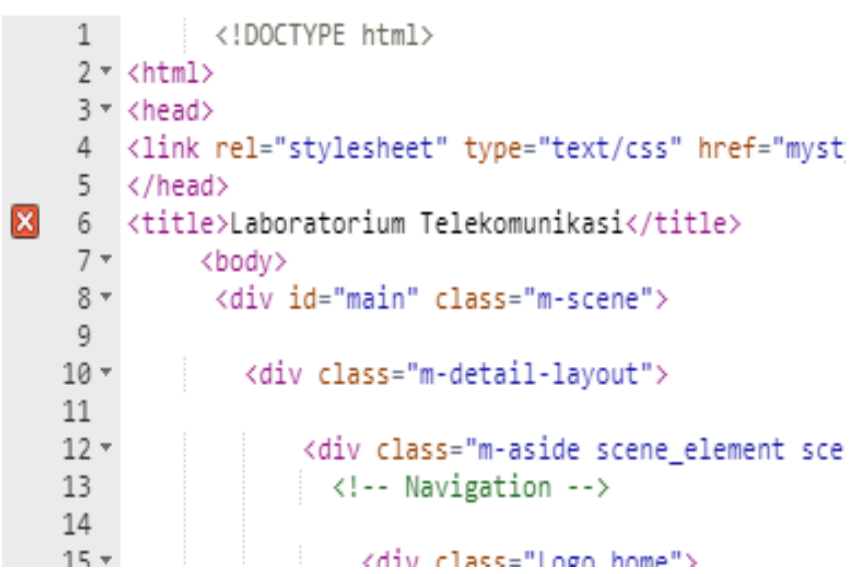

Figure 11. Program code

\section{Implementation Phase}

It was necessary to combine the design of the interface and algorithms with the programming language used i.e. HTML, CSS, JavaScript and PHP programming languages. The implementation steps are described as follows:

- Offline application of program code

The first thing that needs to be done for the offline application of program code is to move the created program code directory into the Xampp application folder. At this stage, the Xampp web server application is used to call the program code and integrate the elements that have been included in the program code. Use of Xampp web server as well as offline MySQL server provider.

- Build a database

The first stage in creating a database is to use the MySQL database offline using the Xampp application. The database is customized with the required tables such as id, URL, room name, description, keywords. As shown in the picture

\begin{tabular}{|c|c|c|c|c|c|c|c|}
\hline \# & Name & Type & Collation & Attributes & Null & Default Comments & Extra \\
\hline 1 & id $?$ & $\operatorname{int}(11)$ & & & No & None & AUTO \\
\hline 2 & url & $\operatorname{varchar}(20)$ & utf8_unicode_ci & & No & None & \\
\hline 3 & nama_ruanagn & $\operatorname{varchar}(20)$ & utf8_unicode_ci & & No & None & \\
\hline 4 & deskripsi & text & utf8_unicode_ci & & No & & \\
\hline 5 & kata_kunci & text & utf8_unicode_ci & & No & & \\
\hline & $\square$ Check all & With selecte & ed: Browse & Chang & & Drop Primary & u \\
\hline
\end{tabular}

Figure 12. Database Structure page

\section{- Registering ID}

After the Application on the local server computer already has a database room, the next process is exclusive Id registration for accounts that gain access to the room, the Id data that has this special access will be stored in the MySQL database. Data stored in the form of Id, Username, Password, and registration date. The password stored in the database is a hash encryption code that cannot be read by the database manager until the user's password cannot be known by anyone.

- $\quad$ Merging Room Pages with VR

Virtual reality view can be utilized by the user with several options, according to the purpose/path that will be passed by the user such as the "main door" or other paths available to the user. Virtual Reality will adjust to the options used by the user by pressing the button below the room map view. Next, the user can see the entrance/road to the room. Users can also continue the view by pressing the arrow keys in the virtual reality view, so the view will change and provide an alive pathwalking experience in virtual mode. Like figure 8 below.

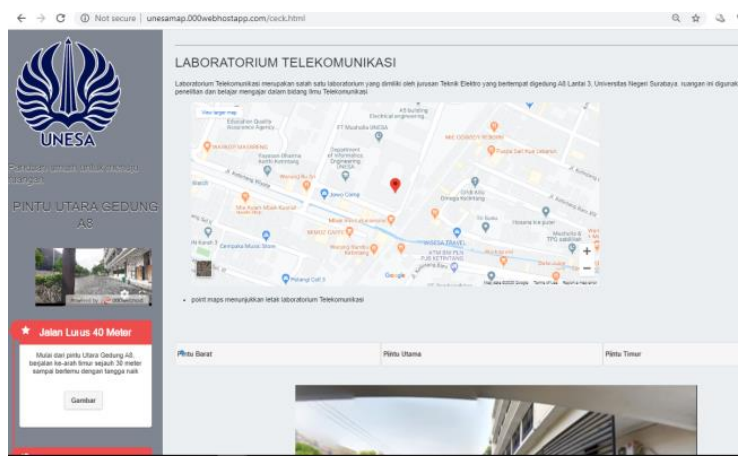

Figure 13. VR merge page

- Increments of directions

Directions are displayed to the left of the room's web page. Similar to virtual reality display The directions shown will adjust to the choice of paths that have been selected by the user. Directions consist of the direction of the road, the description of the distance in units of meters, and the description of the floor to be taken.

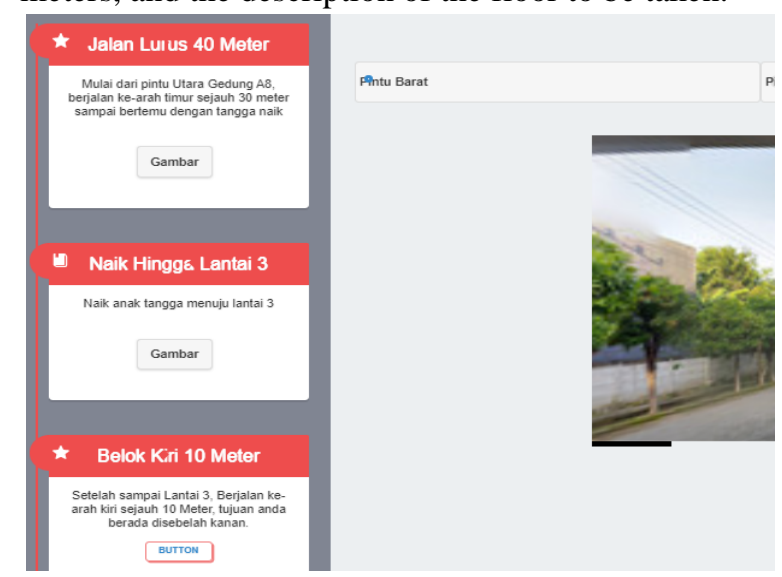

Figure 14. Directions 
- Process of uploading program code data Programs that have been created offline using the Xampp application will then be uploaded to commercial hosting providers, in this study using free hosting from Id Hostinger. In the web view, there will appear a watermark or transparent label indicating that the hosting used is free. All data is uploaded through the admin panel and placed in a public folder

- Database Upload Process

Id Hostinger hosting service provider used in this research has provided MySQL database that has been integrated with its customer hosting, before uploading the database that has been created, the local database needs to be exported first, then the database exported file is uploaded through PhpMyAdmin panel that has been provided by the hosting service provider

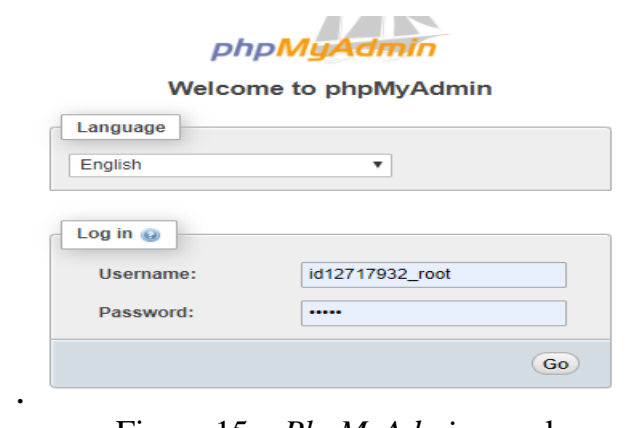

Figure 15. PhpMyAdmin panel page

\section{Testing}

Testing in this study includes testing

\section{- $\quad$ Random Sampling Testing}

Random sampling user testing to find out the actor's response on the IR system of building A8 room that application can meet the user's needs or not. The test was conducted on 30 samples based on questionnaires that were distributed to users randomly. This test is done using questionnaires filled in by the user at the trial stage. The criteria for filling out the grades in the questionnaire include (1) highly inappropriate, (2) inappropriate, (3) appropriate, and (4) very appropriate. The result of the respondent's assessment will be he again with a Likert scale with five criteria among them. (1) Score 5 = Very Decent, (2) Score 4 = Worthy, (3) Score 3 = Fairly Decent, (4) Score 2 = Less Worthy, (5) Score $1=$ Not Worth It.

Analysis of user response is based on the assessment of respondents using a likert scale with assessments such as Table 1.
Table 1. Likert Scale

\begin{tabular}{cc}
\hline Quantitative & Interpretation (\%) \\
\hline Very worth & $84-100$ \\
\hline Worth & $68-83$ \\
\hline Worth Enough & $52-67$ \\
\hline Less Worth & $36-51$ \\
\hline No Worth & $20-35$ \\
\hline
\end{tabular}

In Riduwan [10]. to determine the highest value is used the following formula:

$$
\text { Highest } \text { Value }=\mathrm{n} \times \mathrm{i}_{\max }
$$

Description:

$n=$ Number of respondents

$i=$ Weighted value on quantitative assessment (1-4)

To determine the number of respondents' answers by multiplying the number of respondents in each quantitative assessment by the weight of their value, then the overall results are summed up, using the following formula:

Number of answers $=$

$$
\sum_{1}^{4} n_{i} \mathrm{xi}
$$

Description:

$n_{i}=$ The number of respondents who voted for $i$

$i=$ Weighted value on quantitative assessment (1-4)

The rating results are determined after the sum of respondents' answers, by applying the formula in the following Riduwan (2009).

Rating Result $=\frac{\text { number } \text { of answer }}{\text { highest } \text { value }} \times 100 \%$

After obtaining the rating results, then can be analyzed and then concluded based on the calculation of the rating results obtained. The initial test page view is intended as in Figure 10. Before filling out the questionnaire in the Google Form respondents are asked to visit the URL of the website that has been available. http://unesamap.000webhostapp.com that has been provided. Users are also given a Tutorial service in the form of videos that have been embedded in the home page of the website 


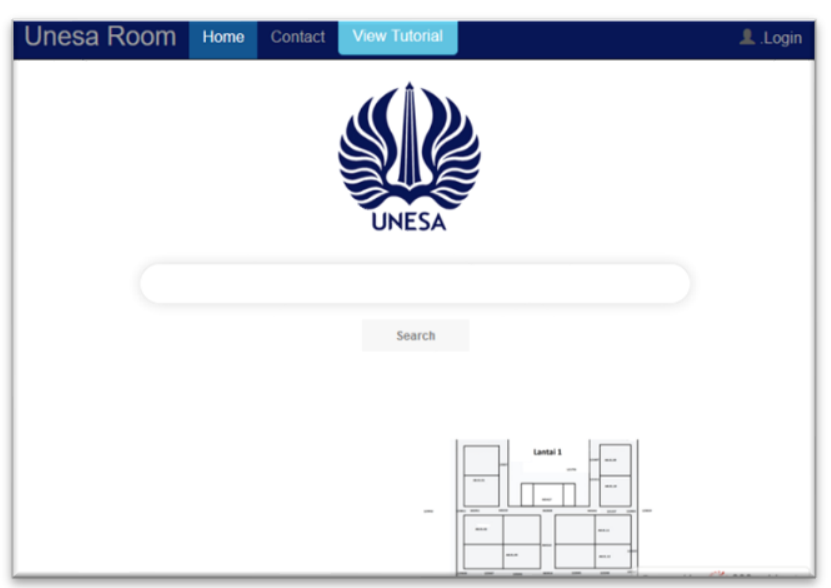

Figure 16. The initial appearance of the website

On the home page, there is a contact menu containing the suggestion form or constraints that you want to convey and the admin contact that can be contacted by email or the number listed. At the bottom, there is a minimap for the floor plan and room layout of Building A8, images that can be displayed ranging from Floor 1 to 4 .

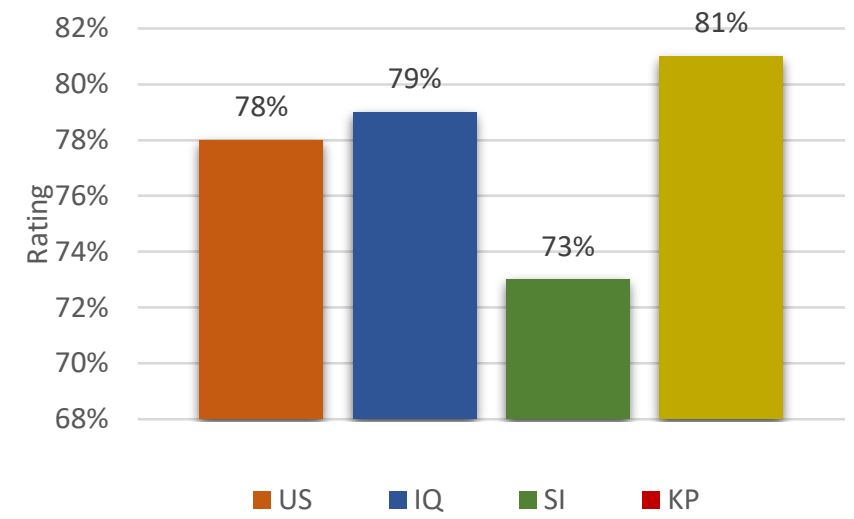

Figure 17. Graph of average usability indicator respondents

Based on the results of the student response rating to the Web Information Retrieval Room in Building A8 Faculty of Engineering Surabaya State University shown in figure 14 can be known that (1) Aspects of Usability got a rating or percentage of $78 \%$, (2) Aspects of information quality / Information Quality get a rating or percentage of $79 \%$, (3) Aspects of interaction quality to user services / Service Interaction Quality get a rating or percentage of $73 \%$, (4) Aspects of user satisfaction get a rating or percentage of $81 \%$. From the percentage of these four aspects can be generated an average rating of $78 \%$.

Data collection is done using questionnaires filled in by users /respondents at the trial stage. Criteria for filling out grades on questionnaires include (1) strongly disagree (STS), (2) disagree (TS), (3) agree (S), and (4) strongly agree (SS). Each indicator has several different questions in number. This assessment was taken from 30 respondents who have filled out the online assessment form through Google Form. The details of the user's payment results are as follows:

a. Usability

Usability testing by users in terms of quality related to the design of the website. The average results of questionnaires on usability indicators are as follows:

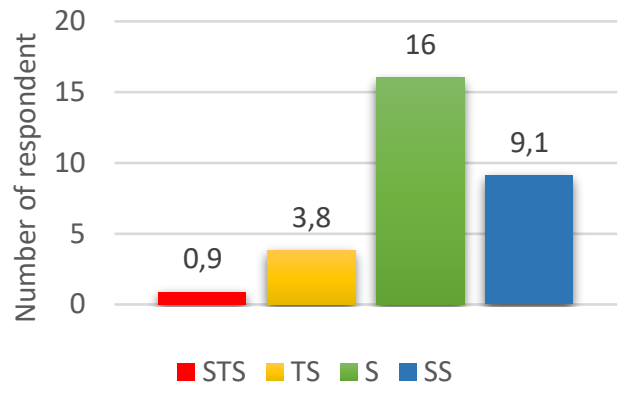

Figure 18. Graph of average usability indicator respondents

b. Information Quality

Testing usability by users in terms of quality related to the content of the website, suitability of information required by users, a complete presentation of content, relevance, and security of information. Average Results of questionnaires on information quality indicator are as follows:

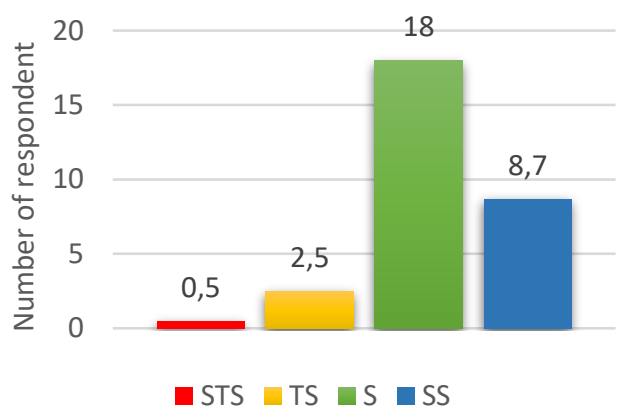

Figure 19. Graph of average respondents information quality indicators

c. Service Interaction Quality / Service Interaction Quality

Pengujian usability by the user in terms of quality related to the service interaction between the user with the developer/administrator and the response of the website service in meeting the expectations of the user. Average Results of questionnaires on information quality indicators are as follows: 


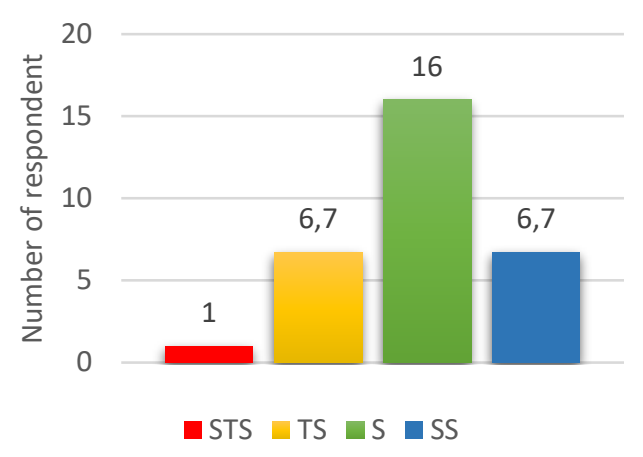

Figure 20. Average rating on Service Interaction

Quality indicator

\section{d. User Satisfaction}

In this indicator, there is an assessment of whether the application is following what the user expects and helps the user to get to the room. From the data, it is known that the summary of the average assessment of respondents in this indicator in Figure 17 below.

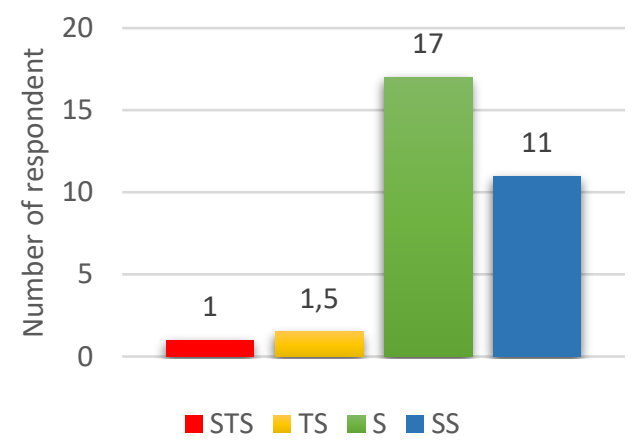

Figure 21. Average rating on User Satisfaction indicators.

\section{- $\quad$ System Testing}

System testing is done directly using a PC/laptop.

\section{Page load speed}

The speed in receiving page data is tested with the network monitor features owned by the Chrome browser. In this test will be done the calculation of the time required in loading elements. Some elements that are calculated data loading time are Html Elements/ web page framework, CSS the largest size of several CSS used in the page, Image Elements with the lingering load time among other image elements in the page, and the total time needed to load all the required elements.
Table 2. Data speed measurement results

\begin{tabular}{|c|c|c|c|c|}
\hline Experiment & HTML & Css & images & All elements \\
\hline Main page & $0,99 \mathrm{~s}$ & $0,628 \mathrm{~s}$ & $0,26 s$ & $15,18 \mathrm{~s}$ \\
\hline $\begin{array}{l}\text { Page } \\
\text { Login }\end{array}$ & $0,28 \mathrm{~s}$ & $0,270 \mathrm{~s}$ & $1,3 \mathrm{~s}$ & $2,60 \mathrm{~s}$ \\
\hline $\begin{array}{c}\text { Contact } \\
\text { Page }\end{array}$ & $1,04 \mathrm{~s}$ & $1,07 s$ & $0,22 s$ & $3,74 \mathrm{~s}$ \\
\hline Search Page & $0,29 \mathrm{~s}$ & $0,13 \mathrm{~s}$ & $0,8 \mathrm{~s}$ & $1,18 \mathrm{~s}$ \\
\hline $\begin{array}{c}\text { Page } \\
\text { A8.03.16 }\end{array}$ & $0,29 \mathrm{~s}$ & $0,03 \mathrm{~s}$ & 1,56 & $11,08 s$ \\
\hline $\begin{array}{c}\text { Page } \\
\text { A8.03.12 }\end{array}$ & $1,26 s$ & $0,03 s$ & $1,23 \mathrm{~s}$ & $12,28 \mathrm{~s}$ \\
\hline $\begin{array}{c}\text { Page } \\
\text { A8.03.13 }\end{array}$ & $0,52 s$ & $0,86 s$ & $9,98 s$ & $17,08 \mathrm{~s}$ \\
\hline $\begin{array}{c}\text { Page } \\
\text { A8.02.02 }\end{array}$ & $0,28 \mathrm{~s}$ & $0,06 s$ & $0,9 \mathrm{~s}$ & $7,14 \mathrm{~s}$ \\
\hline $\begin{array}{c}\text { Page } \\
\text { A8.01.02 }\end{array}$ & 0,28 & $0,09 s$ & $1,27 \mathrm{~s}$ & $7,36 \mathrm{~s}$ \\
\hline \multicolumn{4}{|c|}{ Average page loading } & $8,62 s$ \\
\hline
\end{tabular}

The waiting time measurement data needed to load page data uses a computer unit with AMD A10 Quad Core specifications of $3.5 \mathrm{GHz}, 8 \mathrm{~Gb}$ Ram, $120 \mathrm{~Gb}$ SSD, Windows 10 Operating System and connected to an internet connection with a speed of $10 \mathrm{Mbps}$. From table 2 data obtained the average waiting time to load a page in 8.62 seconds.

Virtual Reality Image Conformity

Image data stored in online storage has been checked and matched to the actual room. From the survey results, it is known that the conformity rate of Virtual Reality data is $100 \%$

Table 3. Virtual Reality data matching results

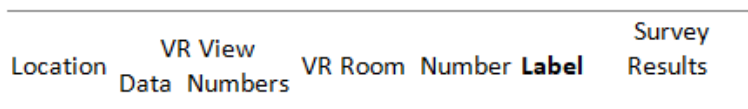

\begin{tabular}{cccc}
\hline 1 & $\mathbf{1 0 2 3 5 1}$ & $\mathbf{A 8 . 0 1 . 0 2}$ & Appropriate \\
\hline 2 & $\mathbf{0 6 5 0 4 2}$ & $\mathbf{A 8 . 0 1 . 1 1}$ & Appropriate \\
\hline 3 & $\mathbf{1 2 3 2 4 1}$ & $\mathbf{A 8 . 0 1 . 0 3}$ & Appropriate \\
\hline 4 & $\mathbf{1 0 1 3 3 6}$ & $\mathbf{A 8 . 0 2 . 0 2}$ & Appropriate \\
\hline 5 & 100300 & $\mathbf{A 8 . 0 2 . 1 1}$ & Appropriate \\
\hline 6 & 095751 & $\mathbf{A 8 . 0 2 . 0 1}$ & Appropriate \\
\hline 7 & 092005 & $\mathbf{A 8 . 0 3 . 1 1}$ & Appropriate \\
\hline 8 & $\mathbf{0 7 3 8 0 6}$ & $\mathbf{A 8 . 0 3 . 1 6}$ & Appropriate \\
\hline 9 & $\mathbf{0 9 1 6 0 8}$ & $\mathbf{A 8 . 0 3 . 1 4}$ & Appropriate \\
\hline 10 & $\mathbf{0 9 4 3 3 7}$ & $\mathbf{A 8 . 0 4 . 0 4}$ & Appropriate \\
\hline 11 & $\mathbf{0 9 4 5 3 1}$ & $\mathbf{A 8 . 0 4 . 1 0}$ & Appropriate \\
\hline 12 & $\mathbf{1 6 5 8 1 9}$ & $\mathbf{A 8 . 0 4 . 1 2}$ & Appropriate \\
\hline
\end{tabular}




\section{CONCLUSION}

From the results of research and testing that has been done, the website of the room search system is rated good by users with an average rating of $78 \%$. It can be concluded that the use of a room search system website equipped with virtual reality is worth using as one of the sources of information to browse and get room information in the A8 building of the Faculty of Engineering, State University of Surabaya. because through the website, information is easy to present and easily accessible. But the use of the website, both in terms of programming and content will have an impact on the performance of servers and networks. Improving the quality of information and services is needed by users to be easily used for users who do not know the Surabaya State University Environment.

From the results, some suggestions to develop a space information retrieval system based on web and virtual reality. The use of hosting can interfere with the convenience of browsing the website because there is a label hosting provider's site contained automatically, The wider environment adopted into virtual reality can provide more diverse information for users.

\section{REFERENCE}

[1] Hasil Survei NasionalPENETRASIPengguna Internet 2018 (Ver. : S 20190518), APJII, 2018.

[2] (2020) Unesa Website [Online], http://unesa.ac.id/, tanggal akses: 16 Januari 2020.

[3] Hasil Survei Nasional PENETRASI Pengguna Internet 2017 (Ver. : S 20190617), APJII, 2017.

[4] Pendit, P.Laxman, Makna Informasi: Lanjutan dari Sebuah Perdebatan, eds. Antonius.B, dkk. Jakarta, Kesaint-Blan, 1992.

[5] Davis, Gordon, Kerangka Dasar Sistem Informasi Manajemen, Bagian I Pengantar Jakarta: Pustaka Binaman Pressindo, 1999.

[6] R. Ariyanti, Khairil, I.Kanedi., "Pemanfaatan Google Maps Api Pada Sistem Informasi Geografis Direktori Perguruan Tinggi DI Kota Bengkulu," Jurnal Media Infotama., Vol. 11, hal. 119-129, Sept. 2015.

[7] A. S. Purnomo., "Implementasi Google Maps Api Dengan PHP Dan Mysql (Kasus : Sistem Informasi Pariwisata)," jurnal informatika, 2013.

[8] P. Sriningrum, "Pengembangan Sistem Temu Kembali Informasi Untuk Pencarian Sarana Kesehatan Diwilayah Solo," jurnal informatika, 2015.

[9] Arikunto, S. Metode Penelitian Kualitatif. Jakarta: BumiAksara, 2008.

[10] Riduwan, Skala Pengukuran Variabel Penelitian, Bandung: CV Alfabeta, 2011.

[11] Ernawati., "Perpustakaan Digital Dalam Temu Kembali Informasi Dengan OPAC," Jurnal Ilmu Perpustakaan dan Informasi, 2018

[12] Andi., "Implementasi Aplikasi SIG Dalam Pengolahan Data Jumlah Penduduk Berbasis Web," Jurnal Elektronik Ilmu Komputer, 2012.

[13] F. Masykur, "Implementasi Sistem Informasi Geografis Menggunakan Google Maps API Dalam Pemetaan Asal Mahasiswa," Jurnal SIMETRIS., vol 5, hal. 181-186, Nov. 2014.

[14] Agus., "Implementasi Google Maps API Dengan PHP Dan MySQL," Universitas Mercu Buana, 2013.

[15] Hariyanto, B. Dasar Informatika \& Ilmu Komputer, 2nd ed., Yogyakarta: Grahallmu, 2008. 